\title{
Determining Stock Return movements of Banking Sector during Global Financial Crisis: An Examination on Emerging Markets of Bangladesh
}

\author{
Rafiqul Bhuyan ${ }^{1}$, Mohammad Sogir Hossain Khandoker ${ }^{2}$, Mahjuja Taznin ${ }^{1}$, Md. Shanur Rahman ${ }^{2}$ \\ and Lamia Akter ${ }^{2}$
}

\begin{abstract}
The objective of the study is to explore various micro and macro variables that affect stock returns of the Dhaka Stock Exchange surrounding the global financial crisis. We collect a sample of 30 listed banks covering the period of 9 years $(2009$ - 2017) for our study. The results indicate that debt to asset ratio (D/A), market capitalization (MKT CAP), interest rate, and foreign exchange rate (ForEx Rate) have positive and significant relationships with stock returns. On the other hand, inflation and leverage have negative and significant influence on stock returns among the eight micro variables and four macroeconomic variables that were used in our analyses.
\end{abstract}

JEL classification numbers: G01, G11, G21

Keywords: Microeconomic \& Macroeconomic Variables, DSE, OLS, Stock Returns and Panel data.

\section{Introduction}

Stock market plays a pivotal role in any economy by serving as a medium of capital flow and an indicator of the ex-ante economic health of the country. One of the recent stock market downfalls in the United States was followed by a severe economic downturn within the US and the global economy. In the aftermath of 2008 financial crisis, the global equity markets have lost nearly US\$32 trillion (Rudd, 2009). A significant drop is also experienced by investors in Dhaka Stock Exchange during 2009-2011 (Nisa \& Nishat, 2011). Among various factors that affect/drive market movements, some of the internal factors (micro) identified in the literature are Dividend, EPS, P/E, Leverage, MKT CAP, and ROE, NAVPS and D /A Ratio (Tsoukalas \& Sil, 1999; Al-Deehani, 2005; Al-Omar \& Al-Mutairi, 2008; Malhotra \& Tandon, 2013). Among the external factors (macro), interest rate, GDP, Inflation Rate, CPI, FDI and Exchange Rate, Strikes and Lock Outs are found to be significant contributors (Khan \& Amanullah, 2012, Tsoukalas \& Sil, 1999; Shubiri, 2010). The influence of macro and microeconomic variables on stock prices has mostly been studied in developed capital markets. However, with the rapid development of economic structure and policy, the importance of capital markets as an intermediary is increasing for developing countries. The literature on Emerging Stock Markets after 1980s (Menike, 2006) has been increasing but there are still many issues behind the fluctuations of the stock market in emerging economies that remain to be investigated. During the global financial crisis of 2008, stock market collapse in Bangladesh have once again renewed the need for such continued research. The purpose of this study is

\footnotetext{
${ }^{1}$ Department of Accounting and Finance, College of Business and Public Affairs, USA

${ }^{2}$ Jagannath University, Dhaka, Bangladesh
}

Article Info: Received: July 4, $2021 \quad$ Published online: September 2, 2021 
to examine the impact of various microeconomic variables as well as macroeconomic variables on stock returns during and after the financial collapse in the banking industry in Bangladesh. Among the micro variables, we consider earnings per share (EPS), net asset value per share (NAVPS), price earnings ratio $(\mathrm{P} / \mathrm{E})$, dividend, leverage, debt to asset ratio (D/A), return on equity (ROE), and market capitalization (MKT CAP). Among the macro variables, we consider foreign direct investment (FDI), foreign exchange rate, inflation rate, and interest rate. We intend to contribute to the literature by addressing which factors influence the stock returns during and after the financial crisis especially in the banking sectors in Bangladesh. In comparison to the existing literature, our paper uses stock returns while other studies use stock prices. We conduct our analysis simultaneously on macroeconomic and microeconomic variables. We are also, to the best of our knowledge, the first to use data specifically from the Bangladesh banking sector during and after the financial collapse after 2008.

The remainder of the paper is presented as follows. Section 2 summarizes the literature. Section 3 shows the research hypotheses, Section 4 describes the data, and empirical strategy. Results are discussed in section 5 and concluding remarks are in section 6.

\section{Literature Review}

The relationship between share price or return and different micro \& macroeconomic variables have been addressed in the academic literature on developed and many developing markets quite extensively. Collins (1957) is one of the earliest studies investigating the determinants of share price for the US market and identified Net Profit, Book Value, Dividend and Operating Earnings are the prominent variables influencing share prices in the US. Another earliest study was conducted by Nelson (1976). His aim was to provide an assessment of monthly stock market returns and inflation in the post war period from 1953 to 1974 based on US data. He successfully accomplished his study and found a negative relationship between stock returns and inflation. To cover the impact of macroeconomic variables on stock prices based on developed countries, there are few studies. Chen, et al., (1986) were one of them. They used seven macroeconomic variables and found that Industrial Production and Changes in Risk Premium were significant to explain share prices. Chen (1991) revealed that Default Spread, Term Spread, Dividend Price Ratio, Industrial Production Growth Rate and One Month T-Bill could forecast future stock market returns. Clare and Thomas (1994) investigated the influence of eighteen macroeconomic factors on share prices in the perspective of UK. They showed that Oil Prices, Bank Lending, Corporate Default Risk and Retail Price Index to be the essential risk factors for the UK share prices. Gjerde and Saettem (1999) inquired the causal relationship between share prices and macroeconomic variables in Norway and found that oil price and share price maintained positive linkage. Mukherjee and Naka (1995) detected strong relationship between Inflation as well as Money Supply, Exchange Rate, Call Money Rate and share prices. Bailey and Chung (1996) found no relation between exchange rate and share prices in Philippine. However, Ibrahim and Aziz (2003) show significant relationship between Exchange Rate, Money Supply, Industrial Production, CPI and share prices. Ahmed (2000) found that there was a linkage between Consumption Expenditures and share prices. Cheung and $\mathrm{Ng}$ (1998) examined the relationships between stock prices and the macroeconomic variables Oil Price, Money Supply, Total Personal Consumption and GNI in Italy, Japan, Germany, USA and Canada. They found a strong co-movement between the predicting macroeconomic variables and share price. Irfan and Nishat (2002) found that Dividend Yield, Payout Ratio and Leverage to be significant factors affecting share prices in Karachi Stock Exchange. Ali (2011) found that inflation and foreign remittances are negatively related with stock prices whereas IPI, P/E and MKT CAP have positive impact on share prices of DSE. Khan et al. (2011) inquired the influence of Dividend Policy on Stock prices in Malaysia through Retention Ratio, EPS, NPAT and RoE. They found that Dividend, EPS, RoE and NPAT maintained positive relation whereas retention ration was in negative relationship with share prices. Okafor and Mgbame (2011) showed that Dividend had maintained positive relation with share prices. Capstaff, 
Klaeboe, Marshall (2004), Black and Scholes (1974) and Pani (2008) also found a positive relationship between dividend policy and share prices. Baskin (1989), on the other hand, showed a negative relation of dividend with share price which is basically known as Dividend Irrelevancy Theory. Similar views were expressed by Uddin (2003), Denis and Osobov (2008) and Chen and Dhiensiri (2009) in their study of Bangladesh, New Zealand, and Nigerian market respectively. Uddin, et. al., (2013) identified what determines the share prices of stock market focusing exclusively on financial sector of Bangladesh. They found that Earnings per share (EPS), Net asset value (NAV), Net profit after tax (NPAT) and Price earnings ratio (P/E) have strong relationship with stock prices. Naveed \& Ramzan (2013) found that size maintained a positive significant relationship while other micro variables have insignificant association with share price. Arshad, et. al., (2016) found that earning per share maintained positive and significant relationship with share prices where book to market value ratio and interest rate have also significant but negative relation with share prices. B/M ratio as key determinant of share prices is found by Nawazish Mirza (2008). Almumani (2014) identified the quantitative factors that influence share prices for the listed banks in Amman Stock Exchange over the period of 2005-2011. The regression results showed that EPS, BV and P/E have significant and positive relationship with market price of share. Shafana (2015) studied to examine the degree and pattern of effect of macroeconomic variables on sector wise share price indices in Sri Lanka over the period from January 2008 to December 2012. The findings from multiple regression analysis revealed that Exchange rate, Treasury bill rate and Inflation rate were common variables to explain the variability of share prices. Tsuyoshi Oyama (1997) investigated the regular relationship between stock prices and macroeconomic variables in Zimbabwe from 1991 to 1994 and found that in 1991-1992 the movement of monetary aggregates caused the large fluctuation in stock prices. Another significant and positive determinant of share prices is BVPS as found by Balkrishnan (1984), Zahir and Khanna (1982) and Sharma (2011). Their studies conclude that a higher BVPS will lead to higher share prices.

An overview of prior studies narrated above on the inquiry of the most influential factors influencing share prices expresses that Dividend paying firms are better valued in the eye of investors as well as $\mathrm{P} / \mathrm{E}$ ratio. Leverage is another special element affecting share prices which indicates that investors add more value to those firms who use less debt as raise in debt decreases the return for investors. Investors also provide high value to those firms who have high EPS as it ensures them a better return. Return on Equity is also important in the eye of investors as it assures the shareholders a specific amount which is earned by using their investment.

Though there are emergence of several studies on the related topic, the outcomes reveal a mixed view regarding the positive and negative impact on share prices. We also cannot find a specific consensus in the variables which are influencing share prices or returns as they are the joint outcome of micro and macroeconomic variables. A gap is also noticed as there is less study regarding the immediate, later, and overall impact of global financial crisis. We are yet to find what micro and macro variables play a pivotal role in influencing stock return especially in the banking sector of Bangladesh. We wish to fill that gap.

\section{Research Hypotheses}

We propose several hypotheses regarding various micro and macro variables to address the relationship between stock return and these factors as follows:

\begin{tabular}{|l|l|}
\hline \multirow{2}{*}{ RoE } & $\mathrm{H} 1_{0}$ : There is no relationship between RoE and stock return. \\
\cline { 2 - 2 } & $\mathrm{H} 1_{1}$ : There is a relationship between RoE and stock return. \\
\hline \multirow{2}{*}{ EPS } & $\mathrm{H} 2_{0}$ : There is no relationship between EPS and stock return. \\
\cline { 2 - 2 } & $\mathrm{H} 2_{1}$ : There is a relationship between EPS and stock return. \\
\hline
\end{tabular}




\begin{tabular}{|c|c|}
\hline \multirow{2}{*}{ NAVPS } & $\mathrm{H}_{0}$ : There is no relationship between NAVPS and stock return. \\
\hline & $\mathrm{H} 3_{1}$ : There is a relationship between NAVPS and stock return. \\
\hline \multirow{2}{*}{ P/E Ratio } & $\mathrm{H} 4_{0}$ : There is no relationship between P/E Ratio and stock return. \\
\hline & $\mathrm{H} 4_{1}$ : There is a relationship between P/E Ratio and stock return. \\
\hline \multirow{2}{*}{ Dividend } & $\mathrm{H} 5_{0}$ : There is no relationship between Dividend and stock return. \\
\hline & $\mathrm{H} 5_{1}$ : There is a relationship between Dividend and stock return. \\
\hline \multirow{2}{*}{ Leverage } & $\mathrm{H6}_{0}$ : There is no relationship between Leverage and stock return. \\
\hline & $\mathrm{H}_{1}$ : There is a relationship between Leverage and stock return \\
\hline \multirow{2}{*}{ D/A Ratio } & $\mathrm{H} 7_{0}$ : There is no relationship between D/A Ratio and stock return \\
\hline & $\mathrm{H} 7_{1}$ : There is a relationship between D/A Ratio and stock return \\
\hline \multirow{2}{*}{ MKT CAP } & $\mathrm{H} 8_{0}$ : There is no relationship between MKT CAP and stock return \\
\hline & $\mathrm{H} 8_{1}$ : There is a relationship between MKT CAP and stock return \\
\hline \multirow{2}{*}{ Interest Rate } & $\mathrm{H} 9_{0}$ : There is no relationship between Interest Rate and stock return \\
\hline & $\mathrm{H} 9_{1}$ : There is a relationship between Interest Rate and stock return. \\
\hline \multirow{2}{*}{ FDI } & $\mathrm{H} 10_{0}$ : There is no relationship between FDI and stock return. \\
\hline & $\mathrm{H} 10_{1}$ : There is a relationship between FDI and stock return \\
\hline \multirow{2}{*}{$\begin{array}{l}\text { Foreign Exchange } \\
\text { Rate (ForEx Rate) }\end{array}$} & $\mathrm{H} 11_{0}$ : There is no relationship between ForEx Rate and stock return. \\
\hline & H11 1 : There is a relationship between ForEx Rate and stock return. \\
\hline \multirow{2}{*}{ Inflation } & $\mathrm{H} 12_{0}$ : There is no relationship between Inflation and stock return \\
\hline & $\mathrm{H} 12_{1}$ : There is a relationship between Inflation and stock return \\
\hline
\end{tabular}

\section{Data}

We use yearly panel data for all the variables under this study covering the period from 2009 to 2017 . The data for micro economic variables (EPS, NAVPS, P/E Ratio, Dividend, Leverage, D/A Ratio, ROE, MKT CAP) are collected from DSE library and website. Additionally, Financial Statements were also used to collect data for micro economic variables obtained from 30 listed banks in the DSE. Data for macroeconomic variables (FDI, Foreign Exchange Rate, Inflation, and Interest Rate were collected from the Bangladesh Bank (Central Bank of Bangladesh) and the World Bank. We know that the global economic \& financial crisis $(2007$ - 2008) has had significant worldwide market collapse and subsequent market collapse in Bangladesh (2010). In this research we attempt to explore market dynamics surrounding the financial collapse. We identify time into three stages: at the time of collapse $(2009-2012)$, after the recovery $(2013-2017)$ and overall $(2009-2017)$ to study stock price behavior at DSE.

4.1 The objectives of this study are:

1. To check the impact of independent internal (Micro) and external (Macro) variables on the dependent variable (Stock Returns) for listed commercial banks of Bangladesh in the Dhaka Stock Exchange (DSE) in three time periods: 
i. We use the $1^{\text {st }}$ time period which consists of four years data (2009 to 2012) to focus on the immediate impact of the global financial crisis \& stock market collapse in Bangladesh on the explanatory power of selected variables.

ii. The $2^{\text {nd }}$ time period, which consists of five years data (2013 to 2017), is used to scrutinize the later impact of the global financial crisis \& stock market collapse in Bangladesh on the explanatory power of selected variables when the stock market in Bangladesh has started to correct or recover.

iii. Third, we analyze a longer time frame, consisting of nine years data (2009-2017), to study the overall impact of the global financial crisis \& stock market collapse in Bangladesh on the explanatory power of selected micro and macroeconomic variables.

We use the following linear regression model to test our hypotheses.

Stock Return $=\beta_{0}+\beta_{1}$ RoE $_{i, t}+\beta_{2}$ EPS $_{i, t}+\beta_{3}$ NAVPS $_{i, t}+\beta_{4}$ P/E Ratio $_{i, t}+\beta_{5}$ Dividend $_{i, t}+\beta_{6}$ Leverage $_{i, t}+$ $\beta_{7}$ D/A Ratio ${ }_{i, t}+\beta_{8}$ MKT CAP $_{i, t}+\beta_{9}$ Interest Rate $_{i, t}+\beta_{10}$ FDI $_{i, t}+\beta_{11}$ ForEx Rate $_{i, t}+\beta_{12}$ Inflation $_{i, t}+\varepsilon_{i, t}$.

\section{Results}

\subsection{Descriptive Statistics}

We have 270 observations over a period of 09 years for our variables. Based on the mean values and standard deviation used to measure the dispersion of the series, we find Stock Returns, NAVPS, P/E Ratio to be highly volatile. Besides Stock Returns, NAVPS has higher standard deviation of 53.79 with mean 38.35 and a range of max and min value respectively 373 and 2.79. [see Appendix Table-01].shows the descriptive statistics for the micro and macroeconomic variables.

\subsection{Correlation Matrix}

The table expresses the results for correlations among explanatory variables affecting stock returns. It is quite clear from the table that stock returns are not only positively but also negatively related to the independent variables which generally means that these variables are somehow affecting the stock returns. As there is no value of correlation greater than 0.9 , then we can say that there is less chance for multicollinearity. [see Appendix Table-02].

\subsection{Normality Test}

In our normality test, we propose that the P-value of more than 0.05 indicates that the distribution is normal and theP-value of less than 0.05 indicates that the distribution breaks the assumption of normality. Table 02 shows that significance values of MKT CAP (.200) are greater than 0.05 which means that this variable is normally distributed in Kolmogorov-Smirnov Normality test. Rest of the variables are violating the assumptions of normality having significance value less than 0.05 . This model has used large sample size, therefore there is no serious departures from the assumption of normality of the error terms were detected. [see Appendix Table-03].

\subsection{Test of Multicollinearity}

Multicollinearity exists when the independent variables are highly correlated having $r=0.9$ or above. But in our previous correlation matrixes, we have observed that there is no such high correlation between independent microeconomic variables as they have value of $r$ less than 0.9. In this circumstances, Variation Inflation Factor (VIF) and Tolerance are mostly used tool to test for multicollinearity. VIF measures the rise of the variance of a coefficient as a consequence of Collinearity where Tolerance measures the percentage of variance in the independent variable that is not accounted for by the other independent variable(s). 
VIF values of 10 or greater and Tolerance value of 0.10 or less indicate the existence of multicollinearity. From the above table, we find that all VIF values are less than 10 and Tolerance values are greater than 0.10 which indicate that the data are free of multicollinearity. [see Appendix Table-04].

\subsection{Model Summary}

For the first time frame from 2009 to $2012,26.2 \%$ of variation in stock returns is explained by the selected micro and macroeconomic variables. In our model, the Durbin-Watson statistic is 2.614 [see Appendix Table-05]. In the second time frame from 2013 to 2017, 39.2\% of variation in stock returns is explained by the selected micro and macroeconomic variables. The increase in explaining power of independent micro and macroeconomic variables in the period of 2013 to 2017 suggests that towards the later part of the global financial crisis and stock market collapse of Bangladesh, the micro and macroeconomic variables have started to influence stock returns more precisely. For, this timeframe we have a Durbin-Watson test value of 2.245[see Appendix Table-06]. For the full time period from 2009 to $2017,25.7 \%$ of variation in stock returns is explained by the selected micro and macroeconomic variables. For this time frame, our model has a Durbin-Watson test value of 2.655 [see Appendix Table07].

\subsection{Coefficients and Regression Line}

Results for the period of 2009-2012 presented in Table 05 in the Appendix show that interest rate and inflation rate have positive and significant impact on stock return. Interest rate has the strongest effect on stock return among the selected micro and macroeconomic variables with a coefficient of 101.324. On the other hand, P/E Ratio, Leverage, D/A Ratio, MKT CAP have a negative and statistically insignificant relationship with stock returns. F-statistics is 0.000 (less than 5\%) suggesting that our results are jointly significant.

Our estimated regression is Stock Return $=-1069.026+101.324$ Interest +54.164 Inflation $+\varepsilon$.

During the period of 2013-2017, our results suggest show that D/A Ratio and MKT CAP have a positive and significant effect on stock return. Leverage, Interest, ForEx Rate and Inflation have a negative and significant relationship with stock return. Interest has the largest effect on stock return among the selected micro and macroeconomic variables with a coefficient of 22.973. On the other hand, RoE, EPS, NAVPS, P/E Ratio, Dividend and FDI have insignificant relationship with stock returns. F-statistics is 0.000 (less than 5\%) which means our results are jointly significant [see Appendix Table-06]. The estimated regression equation for our model is as follows:

Stock Return $=1175.863-1.894$ Leverage +4.56 D/A Ratio +17.566 MKT CAP -22.973 Interest 20.256 ForEx Rate - 12.362 Inflation $+\varepsilon$.

For the total time period, 2009 to 2017, we find only macro variables (ForEx Rate and Inflation) having the significant relationship with stock returns. ForEx Rate has a positive whereas Inflation has a negative and significant impact on stock returns. Moreover, Inflation has the largest negative effect on stock return among the selected micro and macroeconomic variables with a coefficient of 27.907. In terms of overall time frame, It is very interesting that macro variables have the overall impact on stock return rather than micro variables. That means for longer period, macro variables are the main cause behind stock return movements. F-statistics is 0.000 (less than 5\%) which means our results are jointly significant [see Appendix Table-07]. The estimated regression equation is presented as follows:

Stock Return $=-499.305+8.746$ ForEx Rate -27.907 Inflation $+\varepsilon$. 


\section{Conclusion}

Our study contributes to the literature by simultaneously analyzing the impact of macroeconomic and microeconomic variables on stock returns. This paper therefore provides evidence to aid in the resolution of the conflicting mixed outcomes regarding the positive and negative impact on share prices and ambiguity regarding variables which are influencing share prices or returns as they are the joint outcome of micro and macroeconomic variables. We utilize data from the immediate, later, and overall impact of global financial crisis and identify micro and macroeconomic variables that play a pivotal role in influencing stock return especially in the banking sector of Bangladesh. In our analysis, we find that D/A, MKT CAP and ForEx Rate have significant positive relationship with stock returns consistent with the result of Collins (1957), Irfan (2002), Ali (2011), Khan et al. (2011), Okafor and Mgbame (2011), Prabath (2014), Srinivasan (2012), Tsoukalas and Sil (1999), Nazir (2010) and Nirmala (2011). But in case of EPS, NAVPS, P/E , Dividend and RoE, we do not find any significant relationship with stock return contradicting the results of Almumani (2014), Jamil (2016), Uddin and Rahman (2013). Interest Rate ,compared to ForEx Rate and Inflation, has the largest effect, consistent with the results of Nishat (2002), Khan et al. (2011), Hossain (2013) and Arshad (2010), Stephen and Orko (2014), Srinivasan (2012). Our results based on data after the crash, indicate that Dividend and ROE do not have any significant relationship with stock returns contradicting the results of Khan et al. (2011), Okafor and Mgbame (2011). Overall, D/A Ratio, MKT CAP and ForEx Rate have a positive significant relationship with share price which is consistent with Ali (2011), Khan et al. (2011), S.M (2013), Arshad (2010) and Alummani (2014), Sharma (2011) and Srinivasan (2012). On the contrary, NAVPS, Dividend, D/A, MKT CAP and Leverage we find no significant relationship with share price contradictory to the findings of Collins (1957), Irfan (2002). Among the four macroeconomic variables we used, only Exchange rate has a significant but negative relationship with share prices, which is consistent with the results of Ibrahim \& Aziz (2003) and M.A.C.N Shafana (2015), Aurangzeb (2012) and contradict the results of Baily and Chung (1996), Shubiri (2010) and Fisher (1930). On the other hand, FDI does not have any significant relationship with stock returns consistent with Gjerde \& Saettem (1999) and contradictory to Nelson (1976), Ali (2011), Arshad, et.al, (2007). Overall, the implication of this study is that D/A Ratio, MKT CAP, Interest, Inflation and Exchange Rate are the important factors to consider in making investment decisions in the banking industry, along with asymmetric information in context of the stock market in Bangladesh (DSE). The companies (Banks) should follow practices enhancing D/A Ratio and MKT CAP given that these variables have a positive influence and reducing Leverage as it has a negative influence on market value of bank stocks in Bangladesh. Further research with more variables and covering more sectors regarding Bangladesh and a comparative studies with other countries in Indian subcontinent or South East Asian countries would be of value to the literature.

\section{References}

Abdelkarim Almumani (2014). "Determinants of Equity Share Prices of the Listed Banks in Amman Stock Exchange: Quantitative Approach.” International Journal of Business and Social Science, 5(1), 91-104.

Adam, A. M. (n.d.). Macroeconomic Factors and Stock Market Movement: Evidence from Ghana.

Adam, A. M., \& Tweneboah, G. (2008). Mp r a. (11256).

Ahmmed, S. "Immediate Impact of Stock Market Fluctuations on GDP : The Case of Bangladesh." Bangladesh Journal of Business, (April), 1-9, 2012.

Alam, S., Miah, M. R., \& Karim, M. A. "Analysis on Factors that Affect Stock Prices: A Study on Listed Cement Companies at Dhaka Stock Exchange." Research Journal of Finance and Accounting, 7(18), 2222-2847, 2016. 
Ali, M. B. "Impact of Micro and Macroeconomic Variables on Emerging Stock Market Return : A Case on Dhaka Stock Exchange ( DSE )." Interdisciplinary Journal of Research in Business, 1(May), 816, 2011. https://doi.org/10.1071/IS14017

Arshad, Z., Arshaad, A. R., Yousaf, S., \& Jamil, S."Determinants of share prices of listed commercial banks in Pakistan." IOSR Journal of Economics and Finance, 6(2), 56-64, 2015. https://doi.org/10.9790/5933-06235664

Banks, C. "Factors affecting the share price: Evidence from Nepalese Commercial Banks." (June). Nepal Business Journal, 2016. https://doi.org/10.13140/RG.2.1.2141.1440

Chen, Nai-Fu, Richard Roll, and Stephen A. Ross. "Economic Forces and the Stock Market." The Journal of Business 59, no. 3 (1986): 383-403. Accessed August 15, 2021. http://www.jstor.org/stable/2352710

Faruque, O. "Security Analysis of Banking Industry in Bangladesh." Asian Business Review, 8(1), 21$24,2018$.

Gupta, R., Reid, M., Study, E., Surprises, M., \& Returns, S. "Macroeconomic Surprises and Stock Returns in South Africa.” Stellenbosch Economic Working Papers : 05 / 12, 2012.

Ibrahim, M.H., Aziz, H. "Macroeconomic variables and the Malaysian equity market: A view through rolling subsamples", Journal of Economic Studies, Vol. 30 No. 1, pp. 2003. https://doi.org/10.1108/01443580310455241

Khan, M. N. "Determinants of Share Prices at Karachi Stock Exchange." Working paper (March), 2019.

Khan, M. N., \& Amanullah. "Determinants of Share Prices at Karachi Stock Exchange." International Journal of Business and Management Studies, 4(1), 1309-8047, 2012.

Malhotra, N., \& Tandon, K. "Determinants of Stock Prices: Empirical Evidence from NSE 100 Companies." Journal of Business Studies, 3(3), 86-95, 2013.

Mukherjee, T.K. and Naka, A. "DYNAMIC RELATIONS BETWEEN MACROECONOMIC VARIABLES AND THE JAPANESE STOCK MARKET: AN APPLICATION OF A VECTOR ERROR CORRECTION MODEL". Journal of Financial Research, 18: 223-237, (1995). https://doi.org/10.1111/j.1475-6803.1995.tb00563.x

Pradhan, R. S., \& Dahal, S. "Factors Affecting the Share Price: Evidence from Nepalese Commercial Banks.” 2016. SSRN, (June). https://doi.org/10.2139/ssrn.2793469

Sharif, T., Purohit, H., \& Pillai, R. "Analysis of Factors Affecting Share Prices: The Case of Bahrain Stock Exchange." International Journal of Economics and Finance, 7(3), 34-46. 2015. https://doi.org/10.5539/ijef.v7n3p207

Uddin, R. (2013). Determinants of Stock Prices in Financial Sector Companies in Bangladesh- A Study on Dhaka Stock Exchange (DSE). (2003), 471-480.

Wadud, M. A., "Determinants of Share Prices of Listed Commercial Banks in Bangladesh." 2018. SSRN. https://doi.org/10.2139/ssrn.3106243 


\section{Appendix}

Table 1: Descriptive Statistics (2009 - 2017)

\begin{tabular}{|c|c|c|c|c|c|}
\hline & $\mathrm{N}$ & Minimum & Maximum & Mean & Std. Deviation \\
\hline Returns & 270 & -394.47 & 92.39 & -34.21 & 84.32 \\
\hline RoE & 270 & 2.73 & 48.96 & 15.45 & 6.73 \\
\hline EPS & 270 & -4.56 & 133.48 & 7.38 & 14.18 \\
\hline NAVPS & 270 & 2.79 & 373.00 & 38.35 & 53.79 \\
\hline P/E Ratio & 270 & -86.67 & 326.84 & 14.35 & 28.56 \\
\hline Dividend & 270 & 0.00 & 65.00 & 19.40 & 10.94 \\
\hline Leverage & 270 & -16.73 & 68.91 & 11.85 & 5.86 \\
\hline D/A Ratio & 270 & 1.52 & 112.03 & 90.70 & 11.03 \\
\hline MKT CAP & 270 & 9.54 & 11.12 & 10.19 & 0.26 \\
\hline Interest & 270 & 3.07 & 6.89 & 5.13 & 1.17 \\
\hline FDI & 270 & 0.86 & 1.74 & 1.19 & 0.28 \\
\hline ForEx Rate & 270 & 69.04 & 81.86 & 76.37 & 4.25 \\
\hline Inflation & 270 & 5.67 & 8.16 & 6.85 & 0.79 \\
\hline
\end{tabular}


Table 2: Correlation Matrix (2009 - 2017)

\begin{tabular}{|c|c|c|c|c|c|c|c|c|c|c|c|c|c|}
\hline & $\begin{array}{l}\underset{\mathbb{0}}{\Xi} \\
\stackrel{\Xi}{\Xi}\end{array}$ & $\begin{array}{l}\pi \\
0 \\
0 \\
1\end{array}$ & $\frac{\pi}{0}$ & 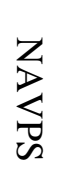 & ते & 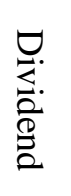 & 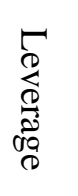 & $\underset{\lambda}{\nabla}$ & 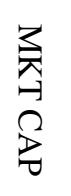 & 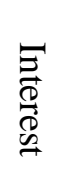 & $\underline{\theta}$ & 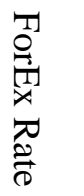 & 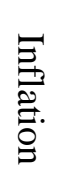 \\
\hline Return & 1.0 & 0.1 & 0.0 & 0.0 & 0.0 & 0.1 & -0.1 & 0.0 & -0.1 & 0.0 & 0.2 & 0.4 & -0.3 \\
\hline RoE & 0.1 & 1.0 & 0.3 & 0.1 & 0.1 & 0.6 & -0.1 & 0.0 & 0.3 & 0.1 & 0.1 & 0.0 & -0.1 \\
\hline EPS & 0.0 & 0.3 & 1.0 & 0.6 & 0.0 & 0.0 & -0.2 & 0.1 & 0.1 & 0.0 & 0.0 & -0.1 & 0.0 \\
\hline NAVPS & 0.0 & 0.1 & 0.6 & 1.0 & 0.0 & 0.0 & 0.2 & 0.0 & 0.0 & 0.1 & 0.1 & 0.0 & 0.0 \\
\hline $\mathrm{P} / \mathrm{E}$ & 0.0 & 0.1 & 0.0 & 0.0 & 1.0 & 0.2 & 0.0 & 0.0 & 0.1 & 0.0 & 0.1 & 0.0 & 0.0 \\
\hline Dividend & 0.1 & 0.6 & 0.0 & 0.0 & 0.2 & 1.0 & -0.1 & -0.1 & 0.3 & 0.0 & -0.1 & -0.1 & 0.0 \\
\hline Leverage & -0.1 & -0.1 & -0.2 & 0.2 & 0.0 & -0.1 & 1.0 & 0.3 & 0.0 & -0.1 & 0.0 & 0.1 & 0.0 \\
\hline $\mathrm{D} / \mathrm{A}$ & 0.0 & 0.0 & 0.1 & 0.0 & 0.0 & -0.1 & 0.3 & 1.0 & 0.1 & 0.0 & 0.1 & 0.0 & -0.1 \\
\hline MKT CAP & -0.1 & 0.3 & 0.1 & 0.0 & 0.1 & 0.3 & 0.0 & 0.1 & 1.0 & 0.2 & 0.0 & -0.2 & 0.0 \\
\hline Interest & 0.0 & 0.1 & 0.0 & 0.1 & 0.0 & 0.0 & -0.1 & 0.0 & 0.2 & 1.0 & 0.6 & -0.2 & -0.1 \\
\hline FDI & 0.2 & 0.1 & 0.0 & 0.1 & 0.1 & -0.1 & 0.0 & 0.1 & 0.0 & 0.6 & 1.0 & 0.3 & -0.2 \\
\hline ForEx Rate & 0.4 & 0.0 & -0.1 & 0.0 & 0.0 & -0.1 & 0.1 & 0.0 & -0.2 & -0.2 & 0.3 & 1.0 & 0.0 \\
\hline Inflation & -0.3 & -0.1 & 0.0 & 0.0 & 0.0 & 0.0 & 0.0 & -0.1 & 0.0 & -0.1 & -0.2 & 0.0 & 1.0 \\
\hline
\end{tabular}


Table 3: Normality Test (2009 - 2017)

\begin{tabular}{|l|l|l|}
\hline Variables & Kolmogorov - Smirnov (Sig.) & Shapiro - Wilk (Sig \\
\hline Returns & 0.000 & 0.000 \\
\hline RoE & 0.000 & 0.000 \\
\hline EPS & 0.000 & 0.000 \\
\hline NAVPS & 0.000 & 0.000 \\
\hline P/E Ratio & 0.000 & 0.000 \\
\hline Dividend & 0.000 & 0.000 \\
\hline Leverage & 0.000 & 0.000 \\
\hline D/A Ratio & 0.000 & 0.000 \\
\hline MKT CAP & $.200^{*}$ & 0.040 \\
\hline Interest & 0.000 & 0.000 \\
\hline FDI & 0.000 & 0.000 \\
\hline ForEx Rate & 0.000 & 0.000 \\
\hline Inflation & 0.000 & 0.000 \\
\hline
\end{tabular}

Table 4: Test of Multicollinearity (2009 - 2017)

\begin{tabular}{|c|c|c|}
\hline \multirow{2}{*}{ Variables } & \multicolumn{2}{|c|}{ Collinearity Statistics } \\
\cline { 2 - 3 } & Tolerance & VIF \\
\hline RoE & 0.557 & 1.794 \\
\hline EPS & 0.448 & 2.231 \\
\hline NAVPS & 0.515 & 1.943 \\
\hline P/E Ratio & 0.942 & 1.061 \\
\hline Dividend & 0.586 & 1.707 \\
\hline Leverage & 0.670 & 1.493 \\
\hline D/A Ratio & 0.851 & 1.175 \\
\hline MKT CAP & 0.822 & 1.217 \\
\hline Interest & 0.411 & 2.432 \\
\hline FDI & 0.397 & 2.519 \\
\hline ForEx Rate & 0.547 & 1.827 \\
\hline Inflation & 0.929 & 1.077 \\
\hline
\end{tabular}


Table 5: Coefficients for the $1^{\text {st }}$ time frame $(2009-2012)$

\begin{tabular}{|c|r|r|}
\hline \multicolumn{2}{|c|}{ Coefficients } \\
\hline & Unstandardized Coefficients B & Level of significance \\
\hline RoE & .153 & .957 \\
\hline EPS & .806 & .454 \\
\hline NAVPS & .063 & .82 \\
\hline P/E Ratio & -.951 & .17 \\
\hline Dividend & 1.525 & .453 \\
\hline Leverage & -.566 & .692 \\
\hline D/A Ratio & -.239 & .381 \\
\hline MKT CAP & -.745 & .989 \\
\hline Interest & 101.324 & 0.000 \\
\hline FDI & 51.486 & .175 \\
\hline ForEx Rate & 46.446 & .105 \\
\hline Inflation & 54.164 & 0.050 \\
\hline Constant & -1069.026 & 0.020 \\
\hline \multicolumn{2}{|r|}{0.000} \\
\hline R square & sig. F change & 2.614 \\
\hline 0.262 & Model Summary $(2009-12)$ & Durbin Watson \\
\hline \multicolumn{2}{|r|}{}
\end{tabular}

Table 6: Coefficients for the $2^{\text {nd }}$ time frame $(2013-2017)$

\begin{tabular}{|c|c|c|}
\hline \multicolumn{3}{|c|}{ Coefficients } \\
\hline & Unstandardized Coefficients B & Level of significance \\
\hline RoE & .224 & .613 \\
\hline EPS & -.043 & .907 \\
\hline NAVPS & -.02 & .77 \\
\hline P/E Ratio & -.011 & .778 \\
\hline Dividend & .061 & .792 \\
\hline Leverage & -1.894 & .053 \\
\hline D/A Ratio & 4.546 & .018 \\
\hline MKT CAP & 17.566 & .028 \\
\hline Interest & -22.973 & 0 \\
\hline FDI & 24.196 & .248 \\
\hline ForEx Rate & -20.256 & 0 \\
\hline Inflation & -12.362 & .018 \\
\hline Constant & 1175.863 & .014 \\
\hline \multicolumn{3}{|c|}{ Model Summary $(2013-2017)$} \\
\hline $\mathrm{R}$ square & sig. F change & Durbin Watson \\
\hline 0.392 & 0.000 & 2.245 \\
\hline
\end{tabular}


Table 7: Coefficients for the Overall time frame $(2009-2017)$

\begin{tabular}{|c|c|c|}
\hline \multicolumn{3}{|c|}{ Coefficients } \\
\hline & Unstandardized Coefficients B & Level of significance \\
\hline RoE & 1.077 & .333 \\
\hline EPS & .225 & .651 \\
\hline NAVPS & 0 & 1 \\
\hline P/E Ratio & -.016 & .903 \\
\hline Dividend & .085 & .878 \\
\hline Leverage & -.804 & .29 \\
\hline D/A Ratio & -.202 & .241 \\
\hline MKT CAP & -.27 & .993 \\
\hline Interest & 5.124 & .49 \\
\hline FDI & -22.793 & .428 \\
\hline ForEx Rate & 8.746 & 0 \\
\hline Inflation & -27.907 & 0 \\
\hline Constant & -499.305 & .036 \\
\hline \multicolumn{3}{|c|}{ Model Summary (2009 - 17) } \\
\hline R square & sig. F change & Durbin Watson \\
\hline 0.257 & 0.000 & 2.655 \\
\hline
\end{tabular}

